\title{
NOKIA PUMA 560 ROBOT MEGFOGÓJÁNAK REKONSTRUKCIÓJA, ADAPTER TERVEZÉSE \& ALKALMAZÁSA KUKA KR5 IPARI ROBOTKAR SZÁMÁRA TERVEZETT CELLÁBAN
}

\section{RECONSTRUCTION, ADAPTER DESIGN, AND APPLICATION OF A NOKIA PUMA 560 ROBOT'S GRIPPER ON A ROBOT CELL INTEGRATED KUKA KR5 INDUSTRIAL ROBOT}

\author{
Vona Gábor, ${ }^{1}$ Apagyi Antal, ${ }^{2}$ Erdei Timotei István, ${ }^{3}$ Husi Géza ${ }^{4}$ \\ Debreceni Egyetem Müszaki Kar, Debrecen, Magyarország \\ ${ }^{1}$ bjgabi@gmail.com \\ 2apagyi.toni@gmail.com \\ ${ }^{3}$ timoteierdei@eng.unideb.hu \\ ${ }^{4}$ husigeza@eng.unideb.hu
}

\begin{abstract}
This summary details the steps that were necessary to fasten a Nokia Puma 560's gripper to a KUKA KR5 industrial robot found at University of Debrecen, Department of Mechatronics and also demonstrates its applications in the robot cell designed around its usage. It also includes the inspection and reconstruction of said gripper, and the 3D designing of its adapter. The adapter is intended for the KUKA KR5 robot, which is later manufactured using PRO-PLA 3D printing. The KUKA KR5 will also have a robot cell designed and built around it, for educational purposes.
\end{abstract}

Keywords: SketchUp make, 3D modelling, gripper, robot .

\section{Összefoglalás}

A Debreceni Egyetem Mechatronikai Tanszék épületének udvarán található Nokia PUMA 560 ipari robot szögmegfogójának a KUKA KR5 ipari robotra történő felszereléséhez vezető lépéseket, valamint a hozzá tervezett és épített gyártócellában történő alkalmazását mutatja be az összefoglaló. Többek közt a robotkar szemrevételezését, a megfogó rekonstrukcióját, 3D adapter tervezését. Elkészül a KUKA KR5 robot és szögmegfogó összekapcsolásáért felelős adapter 3D modellje, majd annak nyomtatással legyártásra kerül PRO-PLA anyagból. A KR5 robot számára cella kerül megtervezésre és megépítésre oktatási célra történő alkalmazásra.

Kulcsszavak: SketchUp make; 3D modellezés; megfogó szerkezet, robot.

\section{Bevezető}

A Debreceni Egyetem Épületmechatronikai Kutatóközpontjában, a „Cyber-Physical and Intelligent Robot Systems Laboratory”-ban, új gyártó berendezések kerültek lefejlesztésre, mely révén az ipar 4.0 által támasztott követelményeknek tudunk eleget tenni [1]. Az ipari szektorban ren- geteg olyan gépegység található, mely mechanikusan épp állapotban maradt fent, de vezérlőegységei vagy programozási metódusa elavult [2]. Olyan referencia példák is vannak, mely esetben az adott hardware-t kellett „renoválni” a tényleges munkavégzés érdekében [3]. 


\section{Nokia PUMA robot állapotának fel- mérése}

\subsection{A robot állapota}

Az ipari robot az épületen kívüli csapadéktól védett helyen található, egy tetővel rendelkező átjáró alatt. Az esős, és téli időjárás okozta magas páratartalom miatt ki van téve a korrózió hatásának. A robotkar már több éve le van selejtezve, üzemképtelen állapotban található, és rajta helyenként korrózió fedezhető fel.

A távlati célok között szerepel, a robotegység teljes rekonstrukciója és új vezérlő egység hozzáillesztése. Azonban a „Cyber-Physical and Intelligent Robot Systems Laboratory” kialakítása nagyobb prioritást élvezett. Tovább a robotcellában lévő KUKA KR5 robot által elvégezhető feladatok száma minimálisnak tekinthető, mivel korlátozott elem számmal rendelkezünk megfogók terén. A fentiek tükrében a Nokia PUMA 560 megfogó egysége kerül renoválásra.

\subsection{A megfogó típusa és állapota}

Kézi erővel nem lehetett a megfogópofákat szétnyitni a korrózió mértéke, és a munka-henger csatlakozási pontjainak kenési hiánya miatt. A KUKA KR5 robot $6 \mathrm{~mm}$-es külső átmérőjü pneumatikus vezetéke került kiválasztásra, mert paramétereiben alkalmas a szögmegfogó müködtetésére. A KR5 roboton használt párhuzamos megfogó táplevegő vezetéke gyorscsatlakozós kivitelü, ellentétben a rekonstruált megfogó menetes csatlakozójával. A levegő vezeték menetes csatlakoztatását az 1. ábra mutatja.

A munkahenger dugattyújának hozzáférhetősége, az alkatrészekről a korrózió eltávolítása, és megfelelő kenés biztosítása érdekében a megfogó szerkezet karjainak eltávolítása elengedhetetlenné vált. A kenés hatására minden működtetéssel egyre gyorsabban mozgott a dugattyú. A pneumatikus munkahenger több-tucatnyi nyitása, illetve összezárása után vált egyenletes működésűvé.

\subsection{Pneumatikus megfogó vezérlése}

Annak érdekében, hogy a pneumatikus megfogót a KUKA KR5 robotkarról vezérelni lehessen,
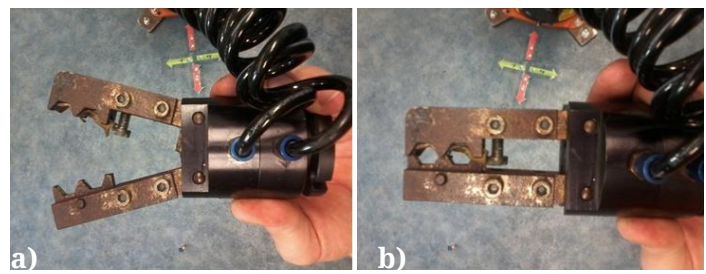

1. ábra. A megfogó nyitott-zárt állapot a levegőáramot egy elektropneumatikus szelep segítségével szükséges vezérelni. ennek érdekében egy Japán gyártmányú, H040-4E2 [4] típusú elővezérelt elektropneumatikus bistabil szelep került kiválasztásra.

A szelep vezérlését a KUKA KR5 vezérlőszekrényéből egy előző fejlesztések során elkészített, tanszéken fejlesztett PLC-k programozását használó eszköz által történt [5]. Az eszköz optikailag leválasztott és reléket vezérlő kimenettel rendelkezik. Így ideálissá vált a szelep vezérléséhez szükséges 24 V-os feszültség kapcsolására.

\section{A megfogó karbantartása felhaszná- láshoz}

Alapszintű szerszámokkal elvégezhető a megfogó karbantartása, az egyszerű felépítése miatt. A rendelkezésre álló szerszámok, és mérőműszerek használata mellett, a költség-hatékonyság volt a legfontosabb szempont.

Az alkatrészek felületi korróziójának eltávolítása különböző szemcseméretű csiszolóvászonnal történt, kivételt képeznek a precíziós kopásálló betétek. Zsír- és portalanítva lettek a szennyeződésektől féktisztító spray-vel. Az összeszerelés a szétbontás fordított sorrendjében készült el. Az összerakás előtti állapotot a 2 . a) ábra szemlélteti.

A megfogó mozgó alkatrészei olajozást kaptak, hogy a megfogó gyorsabban nyisson és zárjon, a korrózió újbóli megakadályozására, az érintkező felületek kopásának csökkentésére, és az üzembiztos működés elérése céljából. Az összeszerelt megfogó állapotát a 2. b) ábra mutatja. A megfogó működtetése 3,2 bar üzemi nyomáson történt. A megfogandó munkadarabnak egy $25 \mathrm{~mm} \times 25 \mathrm{~mm}$ es alumínium kocka került kiválasztásra. A müködés közbeni állapot a 7. ábra szemlélteti.

\section{A megfogó 3D modelljének elkészítése}

A szétszerelt megfogó alkatrészeinek méreteinek lemérése 0-150 mm méréstartományú, és 0,05 [mm] pontosságú precíziós tolómérővel történt.

A 3D modell a SketchUp Make ingyenesen letölthető programmal készült, amely könnyen kezelhető, és felhasználóbarát. Az online adattárházából sok hasznos plug-in program letölthető. A jövőbeli felhasználáshoz elkészült a megfogó 3D

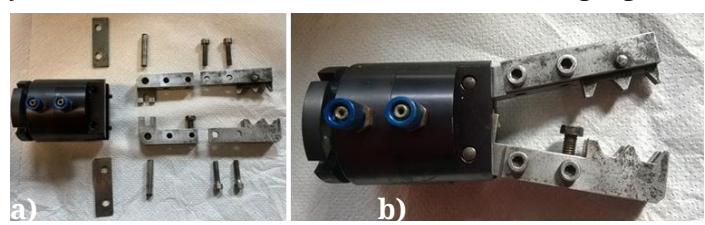

2. ábra. Összeszerelés előtt és után 
modellje. A könnyebb lemodellezés, és a későbbi alkatrészek méreteinek módosítása érdekében külön-külön kerültek elkészítésre, melyet a 3. a) ábra mutat.

Lehetőség van új alkatrészek megtervezésére is. Az egyenként elkészült darabokat csoportosítani lehet, hogy egyszerübben lehessen mozgatni. A programban összeállított megfogó a 3. b) ábra mutatja.

Mivel a megfogó 3D modellje teljes egészében elkészült - elemenként modellezett, a végén csoportosított- így akár új típusú megfogó betétek is tervezhetőek a munkadarab alakjához. A modell alapján prototípusgyártó technológia használatával könnyen és egyszerűen legyártható.

\section{KUKA KR5 adapter tervezése a re- konstruált megfogó részére}

\subsection{Adapter tervezése és 3D modellezése}

A Kuka KR5 robotkarnak is hasonló a furatkiosztása, viszont $1 \mathrm{~mm}$ eltérés van a furatok távolsága között, illetve más átmérőjű csavarok rögzítik a megfogót. Ezáltal szükség volt egy áthidaló alkatrészre, amely rögzíti a robotkart és a szögmegfogót. $\mathrm{Az}$ adapter 5,5 mm-es falvastagsággal került tervezésre, költségtakarékossági okokból és hogy a robotkar hasznos teherbírása kevésbé csökkenjen.

A két adapter összekapcsolásáért minden oldalról egy - egy M5-ös csavar lett kiválasztva, a belső adapterbe hatlapfejü anyatartó lett tervezve, amelybe önzáró kivitelű csavaranya is beépíthető. A robotkarra tervezett alkatrészeket a 4. ábra mutatja.

\subsection{D modell előkészítése nyomtatásra}

Ahhoz, hogy az elkészített fájlt meg lehessen nyitni a Repetier Host programmal a fájlt stl formátumba exportáltam. A Repetier Host a 3D nyomtatók egyik fejlesztői környezete [7]. A SketchUp ingyenesen letölthető adattárából viszont le lehet tölteni egy kiegészítőt, hogy stl formátumba exportálható legyen a már elkészített adapter 3D modellje [6]. Elkészült a paraméterek beállítása, majd szeletelése a CuraEngine programmal, amely egy beépített eszköze a szoftvernek. A szimuláció után megtekinthetővé váltak az eredmények. Az adaptert PLA PRO anyagból terveztem legyártani, mivel a PLA-hoz hasonlóan egyszerüen nyomtatható, de az ütésállósága jelentősen nagyobb. A PLA PRO nyomtatásához nem szükséges a nyomtatóágyat felfüteni, $185-215{ }^{\circ} \mathrm{C}$ között ajánlott az extruder hőmérsékletét beállítani. Hütés hatására nem zsugorodik, és az anyaga nem tüzveszélyes [8].

A két alkatrész kinyomtatása (50\%-os kitöltés mellett) összesen 6 óra 21 percet, és 29,25 m fila-
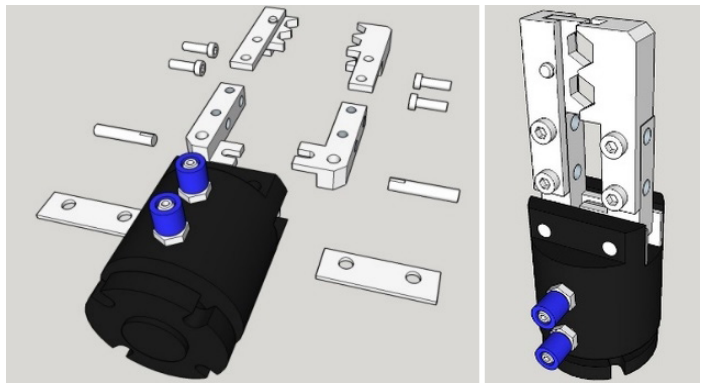

3. ábra. A megfogó elkészített 3D modellje

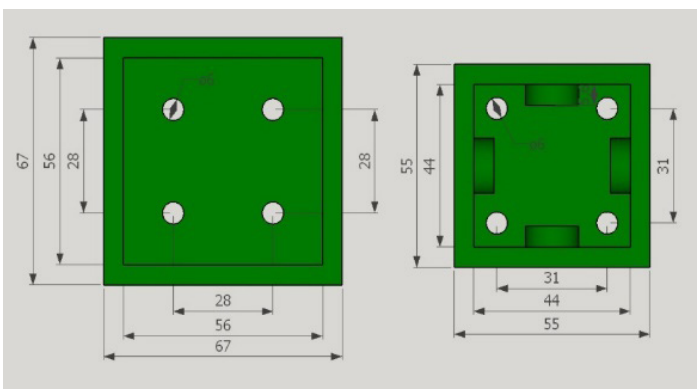

4. ábra. Robotkar és megfogó összekötő adaptere felülnézetben

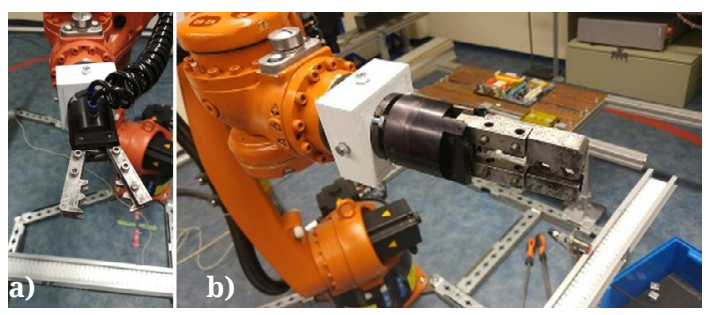

5. ábra. A felszerelt rekonstruált megfogó

mentet vett igénybe. PLA Pro anyaggal számolva ez 659ft anyagköltséget jelent. A megfogó tömege a felszerelt adapterrel és kötőelemekkel $750 \mathrm{~g}$. Az adapterek szimmetrikusak, ezért tetszőlegesen összeilleszthetőek. A robotkarra felszerelt adaptert az 5. ábra mutatja.

A felszerelt eszközzel anyagmozgatási feladat került elvégzésre, amelyen a KUKA KR5 robot a szögmegfogó segítségével anyagmozgatást valósít meg egy Flexlink konvejor bevonásával [9] az ipari munkavégzés szemléltetésére. Munkadarabnak egy $ø 12 \times 40,6$ mm méretü henger alakú alkatrész került kiválasztásra a megfogópofa speciális alakja miatt.

\section{A megfogó alkalmazása a KUKA KR5 ipari robotkar számára tervezett cellában}

Gyártócella került megtervezésre és megépítésre a KUKA KR5 robothoz oktatási céllal. A gyártó- 
cellák mivel különállók, mobilisek ezért szabadon mozgathatók, 6. a) ábra reprezentálja. A szerkezet $40 \mathrm{~mm} \times 40 \mathrm{~mm}$-es aluprofilból áll. Az egyes elemek között a kapcsolatot csavarkötések biztosítják kalapácsfejü, belső kulcsnyílású csavarokkal és T-nútos anyákkal. A talpakat M8-as hatlapfejü csavarok rögzítik az alumínium profilokhoz.

A megépítés után elkészítettem az ipari robot, és a cella 3D modelljét a jövőbeli platformbővítés lemodellezése miatt. A 3D modellt a 6. b) ábra szemlélteti.

Több hallgató bevonásával tervezésre, és megépítésre került egy külső cella, amelyet a 7. ábra mutat. A rendelkezésre álló, leselejtezésre váró elemekből épül fel. A cella a későbbiekben alkalmas védő -plexi- lapokkal történő felszerelésére.

$4 \mathrm{db}$ kamera a robot holtterének figyelése érdekében került felhelyezésre, a sínekre. A kamerák képei monitorokon megtekinthetőek. Megfigyelhetővé válik a gyártócella és véd az illetéktelen személyek ellen. Megoldja, biztonságossá teszi a gyártócella, termelőcella érzékelőinek, beavatkozóinak kábelelvezetését. Ezáltal az oktatás közbeni véletlen balesetek, rongálások, meghibásodások megakadályozhatók.

\section{Következtetések}

A feladat elvégzésre került. A megfogó szerkezet oktatási célokra alkalmas, de a megfogó kopásából, használt jellegéből adódóan minimum 3 bar-os üzemi nyomáson célszerű alkalmazni, a zárási idő csökkentése miatt. Az ipari robot feladatköre bővíthetővé vált.

A rekonstrukció ára alacsony volt, értéke a 1000 ftos értéket nem haladta meg a pneumatikus munkahenger tömítésinek megfelelő állapotából adódóan.

a)
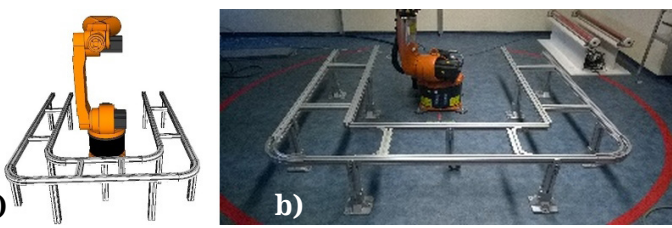

6. ábra. A megépített és $3 D$ modellezett cella

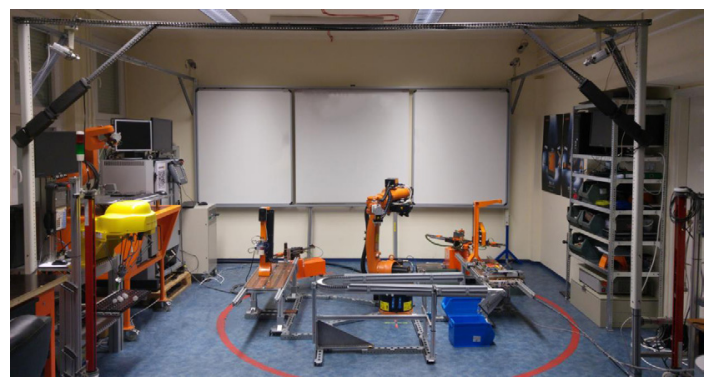

7. ábra. A teljes cella [10]
A karbantartás értéke nagyságrendekkel olcsóbb, mint egy új effektor vétele. Egy új SMC HMT2 2 karos szögmegfogó ára a karokra csavarozható pofák nélkül körülbelül 90.000 Ft. A megfogót a 200 g-mal nehezebb a rekonstruált effekttorhoz képest és nehezebb a felszerelése a robotkarra [11].

Több művelet is elvégezhető, mint a jelenlegi KUKA hegesztőrobot párhuzamos megfogójával, mivel nagyobb a szögmegfogó megfogási tartománya. A jövőben a megfogó továbbfejlesztésének lehetősége adott például érzékelők beépítésével. A megfogó karjaira másfajta pofát lehet tervezni 3D modellező programmal, és 3D nyomtatóval vagy fémmegmunkáló technológia alkalmazásával legyártani.

\section{Köszönetnyilvánítás}

Szeretném megköszönni Dr. Husi Géza tanszékvezető úrnak, valamint a konzulensemnek, Erdei Timotei István tanszéki mérnöknek a dolgozat során nyújtott segítségét.

\section{Szakirodalmi hivatkozások}

[1] Erdei T. I., Molnár Zs., Obinna N. C., Husi G.: Cyber physical systems in mechatronic research centre. MATEC Web Conf. 126, 2017.

[2] Erdei T. I., Molnár Zs., Husi G.: Robot visual and virtual control technology In industrial environment. WoS publication, International Symposium on Small-Scale Intelligent Manufacturing Systems (SIMS ), Narvik, NORWAY- IEEE, Jun 21-24, 2016.

[3] Obinna N. C., Erdei T. I., Molnár Zs., Husi G.: Investigating Configuration Space Singularities of KUKA KR5. International Mechatronical Student micro-Conference IMS $\mu C^{\prime} 2016$.

[4] HUMPHREY H040-4E2. [Hozzáférés: 0212 2019] http://www.smcpneumatics.com/MHT2-32D.html

[5] Erdei T. I., Molnár Zs., Obinna N. C., Husi G.: AGV cyber physical navigation system. FMTÜ - XXII. International Scientific Conference of Young Engineers - Kolozsvár, 23-24.03.2017.

[6] SktechUp Make. [Hozzáférés: 0212 2018] https://www.sketchup.com/download/make.

[7] Repetier- Host. [Hozzáférés: 0212 2018]. https://www.repetier.com/

[8] 3D Jake, PLA PRO. [Hozzáférés: 0212 2018]. https://www.3djake.hu/spectrum/pla-pro-bluelagoon

[9] Flexlink. [Hozzáférés: 0212 2019]. https://www.flexlink.com/en/home/

[10] Erdei T. I.: Ipar 4.0 robot labor fejlesztése LEAN módszertan integrálásával \& gyártási rendszer folyamatok optimalizációja Mixed-Reality alapon: [01 03 2019].

[11] SMC Pneumatics, SMC MHT2-32D. [Hozzáférés: 0212 2018].

http://www.smcpneumatics.com/MHT2-32D.html. 